\section{Comparison of Supplemental Lighting Provided by High-pressure Sodium Lamps or Light-emitting Diodes for the Propagation and Finishing of Bedding Plants in a Commercial Greenhouse}

\author{
Joshua K. Craver ${ }^{1}$ \\ Department of Horticulture and Landscape Architecture, Purdue University, \\ West Lafayette, IN 47907 \\ Jennifer K. Boldt \\ USDA-ARS, Greenhouse Production Research Group, Toledo, OH 43606
}

Roberto G. Lopez ${ }^{2,3}$

Department of Horticulture, Michigan State University, East Lansing, MI 48824

Additional index words. controlled environment agriculture, daily light integral, HPS, LED, plugs

Abstract. High-quality young plant production in northern latitudes requires supplemental lighting (SL) to achieve a recommended daily light integral (DLI) of 10 to $12 \mathrm{~mol} \cdot \mathrm{m}^{-2} \cdot \mathrm{d}^{-1}$. High-pressure sodium (HPS) lamps have been the industry standard for providing SL in greenhouses. However, high-intensity light-emitting diode (LED) fixtures providing blue, white, red, and/or far-red radiation have recently emerged as a possible alternative to HPS lamps for greenhouse SL. Therefore, the objectives of this study were to 1) quantify the morphology and nutrient concentration of common and specialty bedding plant seedlings grown under no SL, or SL from HPS lamps or LED fixtures; and 2) determine whether SL source during propagation or finishing influences finished plant quality or flowering. The experiment was conducted at a commercial greenhouse in West Lafayette, IN. Seeds of New Guinea impatiens (Impatiens hawkeri 'Divine Blue Pearl'), French marigold (Tagetes patula 'Bonanza Deep Orange'), gerbera (Gerbera jamesonii 'Terracotta'), petunia (Petunia $\times$ hybrida 'Single Dreams White'), ornamental millet (Pennisetum glaucum 'Jester'), pepper (Capsicum annuum 'Hot Long Red Thin Cayenne'), and zinnia (Zinnia elegans 'Zahara Fire') were sown in 128-cell trays. On germination, trays were placed in a double-poly greenhouse under a 16-hour photoperiod of ambient solar radiation and photoperiodic lighting from compact fluorescent lamps providing a photosynthetic photon flux density (PPFD) of $2 \mu \mathrm{mol} \cdot \mathrm{m}^{-2} \cdot \mathrm{s}^{-1}$ (ambient conditions) or SL from either HPS lamps or LED fixtures providing a $P P F D$ of $70 \mu \mathrm{mol} \cdot \mathrm{m}^{-2} \cdot \mathrm{s}^{-1}$. After propagation, seedlings were transplanted and finished under SL provided by the same HPS lamps or LED fixtures in a separate greenhouse environment. Overall, seedlings produced under SL were of greater quality [larger stem caliper, increased number of nodes, lower leaf area ratio (LAR), and greater dry mass accumulation] than those produced under no SL. However, seedlings produced under HPS or LED SL were comparable in quality. Although nutrient concentrations were greatest under ambient conditions, select macroand micronutrient concentrations also were greater under HPS compared with LED SL. SL source during propagation and finishing had little effect on flowering and finished plant quality. Although these results indicate little difference in plant quality based on SL source, they further confirm the benefits gained from using SL for bedding plant production. In addition, with both SL sources producing a similar finished product, growers can prioritize other factors related to SL installations such as energy savings, fixture price, and fixture lifespan.

The production of young plants from seed (plugs) for spring bedding plant markets commonly begins during late winter and early spring (Styer, 2003). For high-quality plug production, the recommended DLI is 10 to $12 \mathrm{~mol} \cdot \mathrm{m}^{-2} \cdot \mathrm{d}^{-1}$ (Pramuk and Runkle, 2005; Randall and Lopez, 2014). However, in greenhouses located in northern latitudes, radiation. Thus, through the provision of SL, high-quality young plants can be grown during times of the year when a lack of solar radiation may limit uniform and consistent production (Hernández and Kubota, 2012).

Numerous studies have reported that increasing the DLI with SL from HPS lamps improves young plant quality and reduces subsequent time to flower (TTF) for many bedding plant species (Hutchinson et al., 2012; Lopez and Runkle, 2008; Oh et al., 2010; Pramuk and Runkle, 2005). For example, Oh et al. (2010) observed increased seedling quality as the DLI increased from 7.6 to $17.2 \mathrm{~mol} \cdot \mathrm{m}^{-2} \cdot \mathrm{d}^{-1}$ for petunia (Petunia $\times$ hybrida 'Madness Red') and pansy (Viola $\times$ wittrockiana 'Delta Premium Yellow'). Seedling shoot dry mass (SDM) increased linearly as the propagation DLI increased and TTF was hastened for both species (Oh et al., 2010). Albright et al. (2000) documented a similar linear relationship between SDM and total accumulated radiation, from seeding to final harvest ( $35 \mathrm{~d}$ ), for butterhead leaf lettuce (Lactuca sativa 'Ostinata'). Likewise, Graper and Healy (1992) found that an increased DLI led to increased growth rate and partitioning of carbohydrates into sugars for petunia 'Red Flash' seedlings.

HPS lamps are the current industry standard for SL in greenhouses, commonly providing a $P P F D(400-700 \mathrm{~nm})$ of 70 to 90 $\mu \mathrm{mol} \cdot \mathrm{m}^{-2} \cdot \mathrm{s}^{-1}$ to the plant canopy (Lopez et al., 2017). LEDs are a promising alternative to more traditional lighting sources, such as fluorescent, incandescent, and highintensity discharge lamps, because of their energy-efficiency and long lifespans (Mitchell et al., 2012). However, advancements such as electronic ballasts and double-ended lamps have led to a competitive environment regarding the most efficient and cost-effective source for greenhouse SL. For example, recent studies have reported that commercially available LED fixtures are similar or have become more energy-efficient than doubleended HPS lamps (Nelson and Bugbee, 2014; Wallace and Both, 2016).

LEDs are solid-state semiconductor devices that are able to produce radiation with a very narrow spectrum (Stutte, 2009). Thus, one of the novel benefits from the use of LEDs is the ability to select wavelengths that elicit specific morphological or physiological plant responses (Morrow, 2008). For example, blue wavelengths of radiation (400-500 $\mathrm{nm})$ serve a direct role in mediating stem extension and providing growth inhibition in a variety of crops (Cosgrove, 1981; Kigel and Cosgrove, 1991; Runkle and Heins, 2001).

Previous research found the use of experimental LED fixtures to be a viable SL method for the production of bedding plant seedlings and cuttings (Currey and Lopez, 2013; Randall and Lopez, 2014). For example, Currey and Lopez (2013) found little difference in the growth, morphology, and post-transplant performance of New Guinea impatiens (Impatiens hawkeri 'Celebrette Frost'), geranium (Pelargonium $\times$ hortorum 'Designer Bright Red'), and petunia 'Suncatcher 
Midnight Blue' cuttings produced under SL providing a $P P F D$ of $70 \mu \mathrm{mol} \cdot \mathrm{m}^{-2} \cdot \mathrm{s}^{-1}$ from either HPS lamps or experimental LED arrays with red:blue (R:B) radiation ratios $(\%)$ of 100:0, 85:15, or 70:30. Similarly, Randall and Lopez (2014) found the quality of snapdragon (Antirrhinum majus 'Rocket Pink'), vinca (Catharanthus roseus 'Titan Punch'), impatiens (Impatiens walleriana 'Dazzler Blue Pearl'), geranium 'Bullseye Scarlet', petunia 'Plush Blue', salvia (Salvia splendens 'Vista Red'), French marigold (Tagetes patula 'Bonanza Flame'), and pansy 'Mammoth Big Red' seedlings grown under experimental LED arrays with R:B radiation ratios of 100:0, 85:15, and 70:30 providing a $P P F D$ of $100 \mu \mathrm{mol} \cdot \mathrm{m}^{-2} \cdot \mathrm{s}^{-1}$ was similar to or greater than those produced under HPS lamps. Randall and Lopez (2014) determined seedling quality using the quality index (QI), an objective, integrated, and quantitative measurement by which to evaluate seedlings (Currey et al., 2013).

To our knowledge, no published research has evaluated the use of LED SL in a commercial setting. Therefore, the purpose of the study was to assess the use of LED fixtures manufactured to provide SL as an alternative to traditional HPS lamps for the production of common and specialty bedding plants in a commercial greenhouse. Specifically, the objectives of this study were to 1) evaluate the effect of SL source on the morphology and nutrient concentration of bedding plant seedlings; and 2) determine whether SL source during propagation or finishing influences finished plant quality or flowering.

\section{Materials and Methods}

Plant material and propagation environment. Seeds of New Guinea impatiens 'Divine Blue Pearl', French marigold 'Bonanza Deep Orange', gerbera (Gerbera jamesonii 'Terracotta'), petunia 'Single Dreams White', ornamental millet (Pennisetum glaucum 'Jester'), pepper (Capsicum annuum 'Hot Long Red Thin Cayenne'), and zinnia (Zinnia elegans 'Zahara Fire') were sown in 128-cell trays (14-mL individual cell volume) filled with a commercial soilless medium composed of (by vol.) $65 \%$ peat, $20 \%$ perlite, and 15\% vermiculite (Fafard Super

Received for publication 8 Aug. 2018. Accepted for publication 20 Sept. 2018.

We gratefully acknowledge Maria Del Rosario Del Rio for growth chamber and laboratory assistance, the USDA-NIFA SCRI grant No. 2010-5118121369 for funding, and Philips Lighting for LED lighting. The use of trade names in this publication does not imply endorsement by Purdue University, USDA-ARS, or Michigan State University of products named nor criticism of similar ones not mentioned.

${ }^{1}$ Former graduate student. Current address: Department of Horticulture and Landscape Architecture, Colorado State University, Fort Collins, CO 80523. ${ }^{2}$ Assistant professor and extension specialist.

${ }^{3}$ Corresponding author. E-mail: rglopez@msu.edu.
Fine Germinating Mix; Sun Gro Horticulture, Agawam, MA). Trays were placed in a common greenhouse environment under $86 \%$ shadecloth (8635-O-FB; Ludvig Svensson, Inc., Charlotte, NC), with a constant air temperature set point of $23{ }^{\circ} \mathrm{C}$. The mean \pm SD greenhouse air temperature from 28 Jan. to 9 Mar. 2015 was $22.9 \pm 0.4{ }^{\circ} \mathrm{C}$.

Upon hypocotyl emergence, trays of each species were immediately moved to a commercial greenhouse facility (Galema's Greenhouse; West Lafayette, IN) where propagation SL treatments were established. These treatments consisted of either HPS lamps (600-W; P.L. Light Systems, Beamsville, ON, Canada) or LED toplights (Philips 200-W GreenPower LED toplighting modules; Philips Lighting, Rosemont, IL) with a $\mathrm{R}: \mathrm{B}$ radiation ratio of 90:10 (Fig. 1). Both SL sources provided a constant PPFD of $70 \mu \mathrm{mol} \cdot \mathrm{m}^{-2} \cdot \mathrm{s}^{-1}$ over the course of a $16-\mathrm{h}$ photoperiod (0600-2200 HR). An ambient treatment (no SL) also was established that maintained a 16-h photoperiod through dayextension lighting supplied by compact fluorescent lamps providing a PPFD of 2 $\mu \mathrm{mol} \cdot \mathrm{m}^{-2} \cdot \mathrm{s}^{-1}$ for the duration of the photoperiod. One tray of each species was placed under each of the three radiation treatments, and trays were rotated within each treatment daily to reduce any positional effects on radiation distribution. The propagation greenhouse was maintained at a constant air temperature set point of $23{ }^{\circ} \mathrm{C}$. Environmental data were collected by a data logger (Model CR1000; Campbell Scientific, Inc., Logan, UT) that measured solar $P P F D$ with quantum sensors (LI-190; LI-COR Biosciences, Lincoln, NE) and canopy air temperature using precision thermistors [fan-aspirated solar radiation shields (ST-110; Apogee Instruments, Inc., Logan, UT)] every $15 \mathrm{~s}$ within each treatment. The mean \pm sD DLI from 4 Feb. to 30 Mar. 2015 of the ambient, HPS, and LED SL treatments was $5.4 \pm 1.8,12.1 \pm 3.4$, and $12.3 \pm 4.0 \mathrm{~mol} \cdot \mathrm{m}^{-2} \cdot \mathrm{d}^{-1}$, respectively. The mean \pm SD canopy air temperature from 4 Feb. to 30 Mar. 2015 under HPS and LED SL was $19.8 \pm 3.6$ and $20.0 \pm 1.8^{\circ} \mathrm{C}$, respectively. Seedlings were irrigated as needed with water-soluble fertilizer (Jack's Professional ${ }^{\circledR}$ 20N-0P-16.6K Hi Cal Peat-Lite; J.R. Peters, Inc., Allentown, PA) providing $100 \mathrm{mg} \cdot \mathrm{L}^{-1}$ nitrogen $(\mathrm{N})$.

Propagation data collection. Data were collected on seedling quality and morphology 14 (French marigold and ornamental millet), 21 (pepper, petunia, and zinnia), 28 (New Guinea impatiens), or 35 (gerbera) d after germination. Five seedlings for each species from each of the SL treatments were randomly selected for measurement and analysis. Roots and shoots (leaves and stems) of the seedlings were washed, and nondestructive measurements were taken, which included stem length (measured from the base of the hypocotyl to the shoot apical meristem), stem caliper [measured above the lowest leaf with a digital caliper (digiMax; Wiha, Schonach, Germany)], and total number of nodes. Leaf area (LA) was collected using a LA meter (LI-3100; LI-COR Biosciences) by removing the seedling leaves at the axil. Roots and shoots were then separated and placed in a drying oven at $70{ }^{\circ} \mathrm{C}$ for at least $4 \mathrm{~d}$ before the collection of root dry mass (RDM) and SDM. Based on LA and dry mass measurements, LAR [LA / $(\mathrm{RDM}+\mathrm{SDM})]$ was calculated. In addition, stem length and caliper were used to calculate

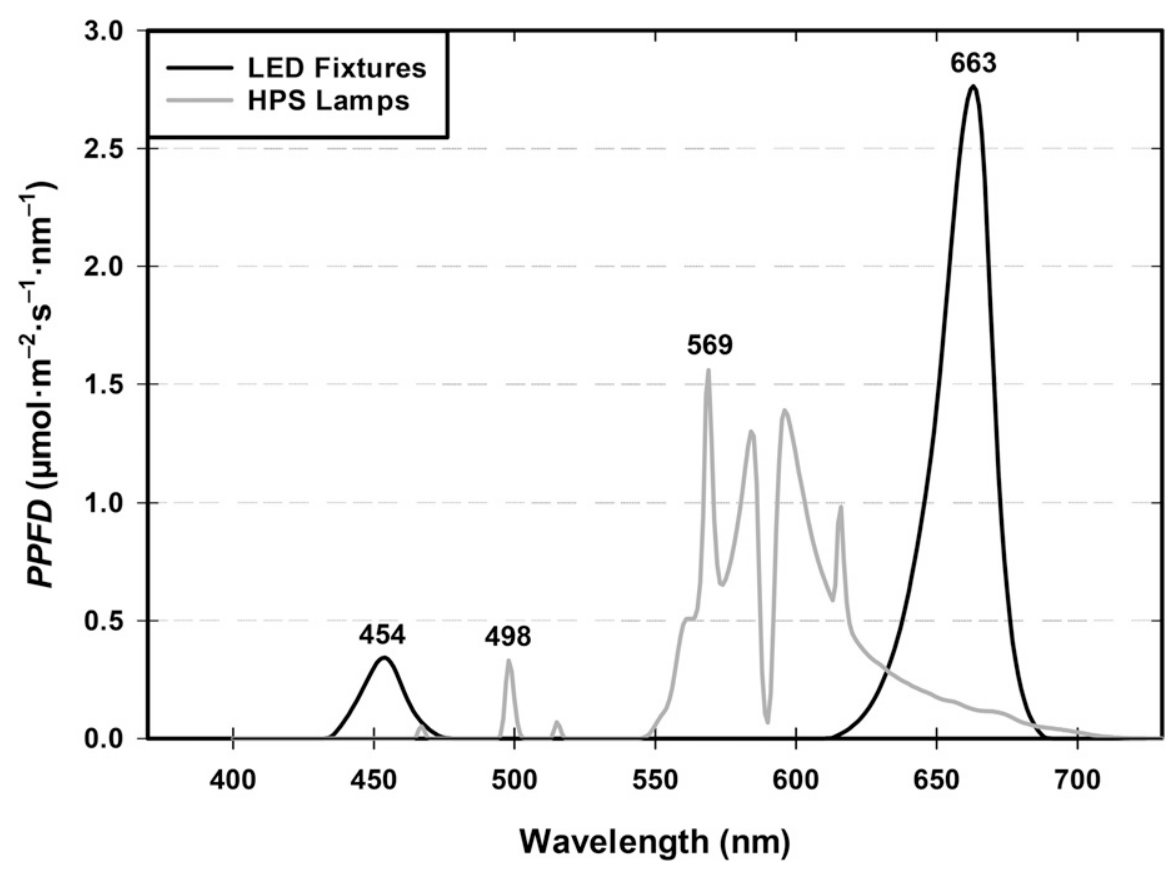

Fig. 1. Spectral quality from 400 to $700 \mathrm{~nm}$ delivered from light-emitting diode (LED) fixtures or highpressure sodium (HPS) lamps providing a photosynthetic photon flux density (PPFD) of $70 \mu \mathrm{mol} \cdot \mathrm{m}^{-2} \cdot \mathrm{s}^{-1}$ at canopy level. 
the sturdiness quotient (SQ; stem caliper/ stem length) of each seedling. The QI [total dry mass $\times($ shoot:root ratio + SQ)] was then calculated according to Currey et al. (2013).

Nutrient analysis. For New Guinea impatiens, pepper, petunia, and zinnia, shoots of five seedlings within each treatment were randomly collected, triple rinsed with deionized water, and placed in a drying oven at $70{ }^{\circ} \mathrm{C}$ for at least $4 \mathrm{~d}$. The combined dry mass of these five seedlings provided a single sample for nutrient analysis, with a total of five samples for each species within each treatment being analyzed for each replication. Foliar $\mathrm{N}$ was determined using a $\mathrm{CHN}$ analyzer (PerkinElmer Series II CHNS/O Analyzer; PerkinElmer Instruments, Shelton, CT). For all other elements, plant tissue from each sample was digested in a microwave (MARS6; CEM Corp., Matthews, NC) and nutrient concentration was determined using inductively coupled plasma optical emission spectroscopy (Thermo iCAP 6300; Thermo Electron Corp., Waltham, MA) as described by Frantz (2013).

Finishing environment. After propagation data collection, 10 randomly selected seedlings from each tray within the HPS and LED SL treatments were transplanted into $11.4-\mathrm{cm}$ diameter $(600-\mathrm{mL})$ containers (Dillen Products, Middlefield, $\mathrm{OH}$ ) filled with a commercial soilless medium composed of (by vol.) $75 \%$ peat, $20 \%$ perlite, and $5 \%$ vermiculite (Fafard 2; Sun Gro Horticulture). Transplants were moved into a separate finishing greenhouse with $18 / 15^{\circ} \mathrm{C}$ (day/night) air temperature set points. Each set of 10 transplants was equally distributed into one of two SL treatments for finishing, which consisted of either HPS lamps (600-W; P.L. Light Systems) or LED toplights (Philips 200-W GreenPower LED toplighting modules; Philips Lighting) providing a constant $P P F D$ of $70 \mu \mathrm{mol} \cdot \mathrm{m}^{-2} \cdot \mathrm{s}^{-1}$ over the course of a $16-\mathrm{h}$ photoperiod (0600-2200 HR). Instantaneous $P P F D$ was collected using a data logger (Model CR1000; Campbell Scientific, Inc.) with quantum sensors (LI-190; LI-COR Biosciences.). In addition, mean air temperature within each SL treatment was recorded every $15 \mathrm{~min}$ by a data logger (WatchDog 2800 Weather Station; Spectrum Technologies, Aurora, IL). The mean \pm SD DLI from 23 Mar. to 9 June 2015 under the HPS and LED SL treatments was $14.5 \pm 4.8$ and $15.0 \pm 5.2$ mol $\cdot \mathrm{m}^{-2} \cdot \mathrm{d}^{-1}$, respectively. The mean $\pm \mathrm{SD}$ daily air temperature from 23 Mar. to 9 June 2015 under HPS and LED SL was $20.5 \pm 2.4$ and $20.1 \pm 2.4^{\circ} \mathrm{C}$, respectively. As necessary, plants were irrigated using a water-soluble fertilizer (Jack's Professional ${ }^{\circledR} 20 \mathrm{~N}-4.4 \mathrm{P}-$ 16.6K General Purpose; J.R. Peters, Inc.) providing $200 \mathrm{mg} \cdot \mathrm{L}^{-1} \mathrm{~N}$.

Finishing environment data collection. After transplant, plants were evaluated daily for first flower with all petals fully reflexed to calculate the TTF from the transplant date. Data were subsequently collected on plant height, number of nodes below the first open flower, and SDM. For ornamental millet, plants were harvested $42 \mathrm{~d}$ after transplant, and TTF was not collected.

Statistical analysis. The experiment was laid out in a completely randomized design, with trays assigned randomly to each SL treatment and species evaluated separately. The experiment was replicated twice over time for each of the species and morphological and nutrient data were pooled. The effect of SL treatment was compared by analyses of variance using SAS (SAS version 9.3; SAS Institute, Cary, NC) mixed model procedure (PROC MIXED) and Tukey's honestly significant difference test at $P \leq 0.05$ for seedling data. The effect of SL source during propagation $(\mathrm{P})$, finishing $(\mathrm{F})$, and their interaction $(\mathrm{P} \times \mathrm{F})$ was compared by analyses of variance for finishing data (Table 1).

\section{Results}

Stem length and caliper. The effect of SL treatment on stem length was variable among species (Fig. 2A). For New Guinea impatiens, stem length under ambient conditions was $23 \%$ and $12 \%$ greater than those produced under LED and HPS SL, respectively. Conversely, French marigold and ornamental millet had greater stem lengths under HPS SL. Specifically, stem length of French marigold was 14\% greater under HPS compared with LED SL, whereas stem length of ornamental millet was $24 \%$ greater under HPS SL compared with ambient conditions. For the remaining four species, no significant differences in stem length were observed between radiation treatments.

Regardless of species, stem caliper was reduced for seedlings produced under ambient conditions compared with LED or HPS SL (Fig. 2B). For example, stem caliper was $18 \%$ and $20 \%$ (New Guinea impatiens), $36 \%$ and $35 \%$ (French marigold), $45 \%$ and $54 \%$ (ornamental millet), $15 \%$ and $22 \%$ (petunia), and $19 \%$ and $21 \%$ (zinnia) greater under LED and HPS SL, respectively, compared with ambient conditions. However, no differences in stem caliper were observed between SL treatments for any of the species.

LA and nodes. Generally, LA was greatest for seedlings produced under SL (Fig. 2C). For example, LA was $76 \%$ and $72 \%$ (gerbera),
$62 \%$ and $63 \%$ (French marigold), $115 \%$ and $116 \%$ (ornamental millet), $54 \%$ and $105 \%$ (petunia), and $94 \%$ and $102 \%$ (zinnia) greater under LED and HPS SL, respectively, compared with ambient conditions. In addition, LA of petunia increased $33 \%$ under HPS compared with LED SL. LAR was greatest for gerbera, New Guinea impatiens, French marigold, pepper, petunia, and zinnia produced under ambient radiation compared with both LED and HPS SL (Fig. 3). In addition, LAR was $38 \%$ and $34 \%$ greater under HPS compared with LED SL for pepper and petunia, respectively.

The number of nodes increased for seedlings produced under SL compared with ambient conditions for five of the species evaluated (Fig. 2D). For example, the number of nodes increased by 33\% and 33\% (gerbera), $25 \%$ and $35 \%$ (French marigold), $55 \%$ and $50 \%$ (ornamental millet), $38 \%$ and $52 \%$ (petunia), and 19\% and 16\% (zinnia) under LED and HPS SL, respectively, compared with ambient conditions. However, differences in the number of nodes between SL treatments were not observed.

Root and shoot dry mass. The greatest accumulation of RDM and SDM occurred under LED or HPS SL for all species (Fig. 2E and $2 \mathrm{~F}$ ). For example, RDM increased $345 \%$ and $296 \%$ (gerbera), $183 \%$ and $139 \%$ (New Guinea impatiens), 392\% and 340\% (French marigold), $112 \%$ and $100 \%$ (ornamental millet), $455 \%$ and $381 \%$ (petunia), and $369 \%$ and $297 \%$ (zinnia) under LED and HPS SL, respectively, compared with ambient conditions. Similarly, SDM increased by $165 \%$ and $131 \%$ (gerbera), $68 \%$ and $63 \%$ (New Guinea impatiens), 162\% and 119\% (ornamental millet), 204\% and 218\% (petunia), and $195 \%$ and $195 \%$ (zinnia) under LED and HPS SL, respectively, compared with ambient conditions. No significant differences in RDM or SDM were observed between SL sources.

$S Q$ and $Q I$. The SQ for gerbera, New Guinea impatiens, and ornamental millet was greatest under LED and HPS SL, with no significant differences observed between the two SL sources (Fig. 2G). However, the SQ of French marigold, pepper, and zinnia grown under LED SL was $15 \%, 23 \%$, and

Table 1. Analyses of variance (ANOVA) for the effects of supplemental lighting source during propagation $(\mathrm{P})$, finishing $(\mathrm{F})$, or their interaction $(\mathrm{P} \times \mathrm{F})$ on time to flower $(\mathrm{TTF})$, height at flowering $(\mathrm{Ht})$, number of nodes below first open flower, and shoot dry mass (SDM) at flowering for New Guinea impatiens (Impatiens hawkeri 'Divine Blue Pearl'), French marigold (Tagetes patula 'Bonanza Deep Orange'), gerbera (Gerbera jamesonii 'Terracotta'), petunia (Petunia $\times$ hybrida 'Single Dreams White'), ornamental millet (Pennisetum glaucum 'Jester'), and zinnia (Zinnia elegans 'Zahara Fire').

\begin{tabular}{|c|c|c|c|c|c|c|c|c|c|c|c|c|}
\hline & \multicolumn{3}{|c|}{ TTF } & \multicolumn{3}{|c|}{$\mathrm{Ht}$} & \multicolumn{3}{|c|}{ Nodes } & \multicolumn{3}{|c|}{ SDM } \\
\hline & $\mathrm{P}$ & $\mathrm{F}$ & $\overline{\mathrm{P} \times \mathrm{F}}$ & $\bar{P}$ & $\mathrm{~F}$ & $\bar{P} \times \mathrm{F}$ & $\bar{P}$ & $\mathrm{~F}$ & $\overline{P \times F}$ & $\bar{P}$ & $\mathrm{~F}$ & $\mathrm{P} \times \mathrm{F}$ \\
\hline Gerbera & $\mathrm{NS}^{\mathrm{Z}}$ & NS & NS & NS & NS & NS & NS & NS & NS & $*$ & NS & NS \\
\hline Impatiens & NS & NS & NS & NS & NS & NS & NS & NS & NS & $* *$ & NS & NS \\
\hline Marigold & NS & NS & NS & NS & NS & NS & NS & NS & NS & NS & NS & NS \\
\hline Millet & $-y$ & - & - & ns & $* *$ & NS & NS & NS & NS & NS & $*$ & NS \\
\hline Petunia & NS & NS & NS & NS & * & NS & $*$ & NS & NS & NS & NS & NS \\
\hline Zinnia & NS & $*$ & NS & NS & NS & NS & NS & NS & NS & NS & NS & NS \\
\hline
\end{tabular}

$\mathrm{z}_{\mathrm{NS}}, *, * *, * * *$ Nonsignificant or significant at $P \leq 0.05,0.01$, or 0.001 , respectively.

${ }^{\mathrm{y}}$ Ornamental millet was harvested $42 \mathrm{~d}$ after transplant and TTF was not collected. 


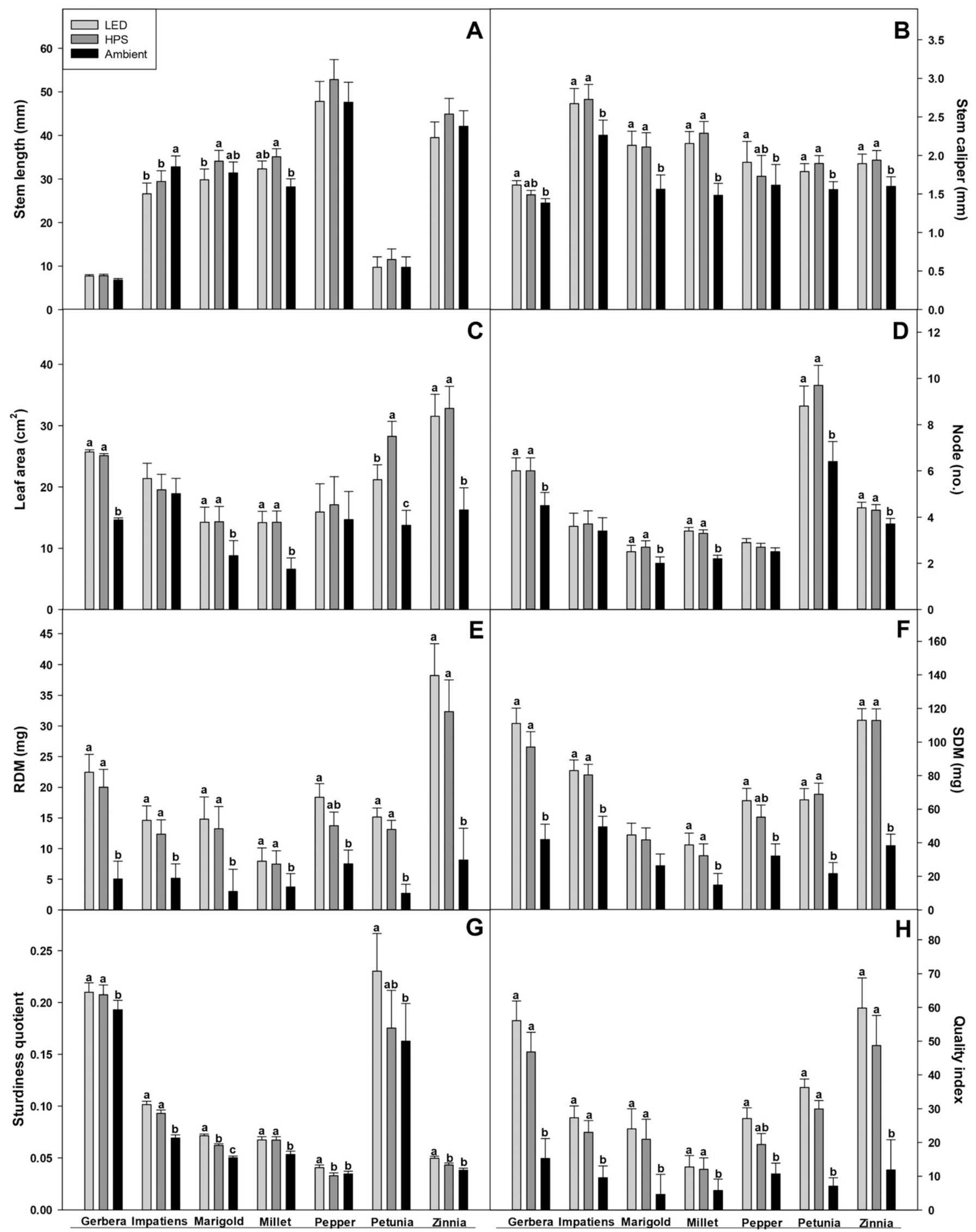

Fig. 2. (A) Stem length, (B) stem caliper, (C) leaf area, (D) number of nodes, (E) root dry mass (RDM), (F) shoot dry mass (SDM), (G) sturdiness quotient, and (H) quality index for New Guinea impatiens, French marigold, gerbera, pepper, petunia, ornamental millet, and zinnia seedlings collected 28, 14, 35, 21, 21, 14, and $21 \mathrm{~d}$ after germination, respectively (mean $\pm \mathrm{SD} ; \mathrm{n}=10$ ). Seedlings were grown under supplemental lighting provided by light-emitting diode (LED) fixtures, high-pressure sodium (HPS) lamps, or no supplemental lighting (ambient). Means sharing a letter are not statistically different by Tukey's honestly significant difference test at $P \leq 0.05$. 


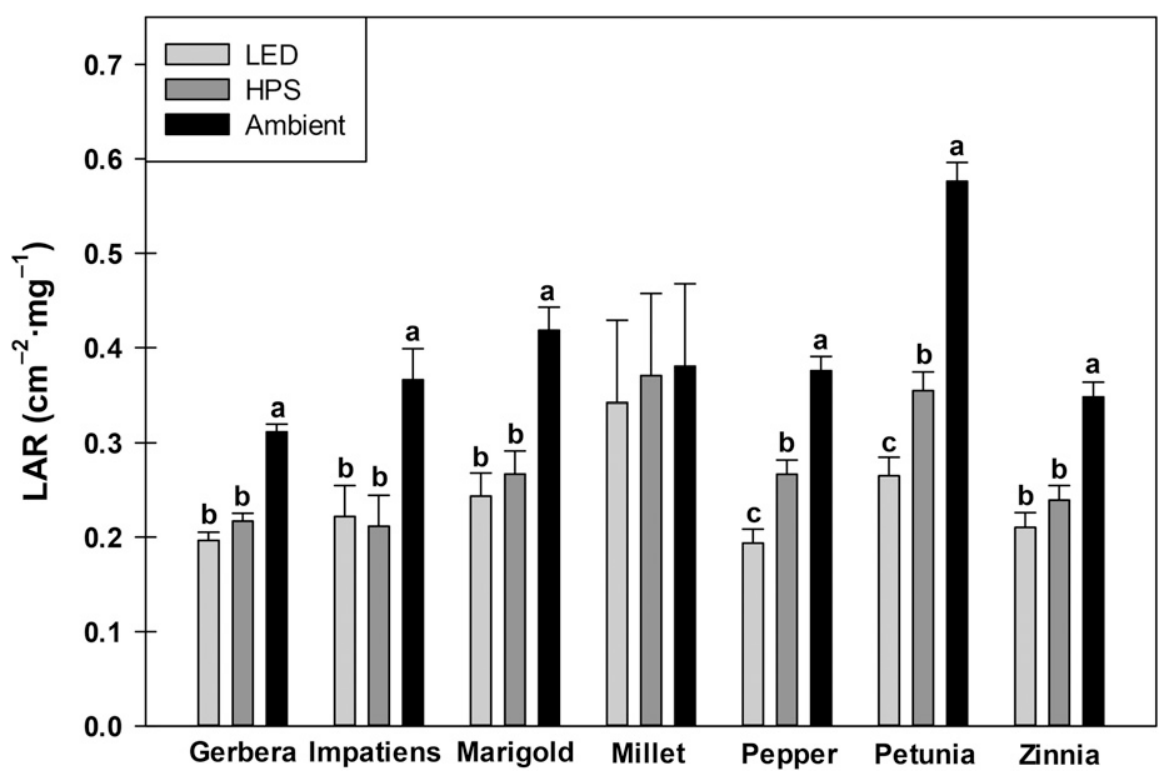

Fig. 3. Leaf area ratio (LAR) for New Guinea impatiens, French marigold, gerbera, pepper, petunia, ornamental millet, and zinnia seedlings collected 28, 14, 35, 21, 21, 14, and $21 \mathrm{~d}$ after germination, respectively (mean $\pm \mathrm{SD} ; \mathrm{n}=10$ ). Seedlings were grown under supplemental lighting provided by lightemitting diode (LED) fixtures, high-pressure sodium (HPS) lamps, or no supplemental lighting (ambient). Means sharing a letter are not statistically different by Tukey's honestly significant difference test at $P \leq 0.05$.

$15 \%$ greater, respectively, than those produced under HPS SL.

Generally, QI values were greater under LED and HPS SL compared with ambient conditions (Fig. 2H). For example, the QI increased by $266 \%$ and $206 \%$ (gerbera), $186 \%$ and $141 \%$ (New Guinea impatiens), $422 \%$ and $355 \%$ (French marigold), $120 \%$ and $108 \%$ (ornamental millet), $412 \%$ and $322 \%$ (petunia), and $405 \%$ and $311 \%$ (zinnia) under LED and HPS SL, respectively, compared with ambient conditions. Differences in QI values between LED and HPS SL were not observed.

Nutrient concentration. For many of the macronutrients, concentrations were greatest under the ambient treatment for all four species evaluated (Table 2). For example, $\mathrm{N}$, phosphorus $(\mathrm{P})$, potassium $(\mathrm{K})$, sulfur $(\mathrm{S})$, calcium $(\mathrm{Ca})$, and magnesium $(\mathrm{Mg})$ concentrations of petunia were $69 \%$ and $41 \%(\mathrm{~N})$, $64 \%$ and $64 \%(\mathrm{P}), 40 \%$ and $22 \%(\mathrm{~K}), 9 \%$ and $9 \%(\mathrm{~S}), 22 \%$ and $9 \%(\mathrm{Ca})$, and $33 \%$ and $17 \%$ $(\mathrm{Mg})$ greater under ambient conditions compared with LED and HPS SL, respectively. In addition, specific macronutrient concentrations were lower under LED SL for New Guinea impatiens, petunia, and zinnia compared with HPS SL. For example, concentrations of $\mathrm{N}, \mathrm{K}, \mathrm{Ca}$, and $\mathrm{Mg}$ for petunia grown under HPS SL were $20 \%, 11 \%, 12 \%$, and $14 \%$ greater, respectively, than those produced under LED SL. Similarly, concentrations of $\mathrm{N}, \mathrm{K}$, and $\mathrm{Mg}$ for zinnia grown under HPS SL were $13 \%, 15 \%$, and $11 \%$ greater, respectively, than those produced under LED SL.

Similar trends were measured regarding micronutrients, with greater concentrations often observed for seedlings grown under ambient conditions (Table 3 ). In addition, micronutrient concentrations were often lower under LED compared with HPS SL. For example, concentrations of boron (B), iron $(\mathrm{Fe})$, manganese $(\mathrm{Mn})$, and zinc for zinnia grown under HPS SL were 13\%, $183 \%, 121 \%$, and $23 \%$ greater, respectively, than those produced under LED SL. Similarly, concentrations of B, copper, $\mathrm{Fe}, \mathrm{Mn}$, and molybdenum for New Guinea impatiens grown under HPS SL were $15 \%$, $28 \%, 126 \%, 108 \%$, and $21 \%$ greater, respectively, than those produced under LED SL.

Finishing. SL source during both propagation and finishing had little effect on TTF or finished plant quality for most species (Table 1). Although no interaction between propagation and finishing SL source was observed, main effects were occasionally significant. For example, the main effect of finishing SL source on TTF was significant for zinnia, and plants finished under HPS SL flowered an average of $2 \mathrm{~d}$ earlier compared with LED SL (data not shown). The main effect of finishing SL source on height was significant for ornamental millet and petunia, with a $21 \%$ and $8 \%$ increase, respectively, for plants finished under HPS compared with LED SL (data not shown). Similarly, ornamental millet displayed a $78 \%$ increase in SDM when finished under HPS compared with LED SL (data not shown). When grown under HPS SL during propagation, petunia had one additional node at flowering compared with those grown under LED SL (data not shown). The main effect of propagation SL source on SDM was significant for gerbera and New Guinea impatiens, with a 33\% and $54 \%$ increase, respectively, for plants grown under LED compared with HPS SL (data not shown).

\section{Discussion}

Desired qualities for bedding plant plugs include a compact habit, thick stem caliper, high root and shoot biomass, and a reduced LA to prevent mutual shading (Oh et al., 2010; Pramuk and Runkle, 2005; Randall and Lopez, 2014). Plugs representing these qualities are generally more easily processed, shipped, and mechanically transplanted (Pramuk and Runkle, 2005). Generally, under a low-radiation environment, stem length and LA will increase through a physiological response known as shade avoidance (Franklin, 2008). In the present study, it was anticipated that plugs grown under ambient radiation would exhibit symptoms of shade avoidance due to the low DLI. However, the results for stem length varied among species, and LA was generally greatest for plugs receiving SL. Specifically, gerbera, French marigold, ornamental millet, petunia, and zinnia all displayed greater LA under LED or HPS SL compared with ambient radiation. For these five species, increases in node number also occurred under LED and HPS SL compared with ambient radiation. Thus, the increase in LA under SL was likely due in part to an increase in leaf number (nodes). However, seedlings grown under ambient radiation displayed symptoms of shade avoidance through increased LAR compared with LED and HPS SL. LAR provides a measure of LA per unit of total dry mass (Hunt and Cornelissen, 1997). Thus, more resources were allocated toward increased LA, rather than leaf thickness, under ambient radiation conditions to increase radiation interception. Although LA and stem length trends were not necessarily indicative of an insufficient DLI under ambient radiation conditions, greater LAR values provide evidence for shade avoidance.

For petunia plugs, LA and LAR were smaller under LED compared with HPS SL. LAR of pepper also decreased under LED compared with HPS SL. These responses may be due to the increased proportion of blue wavelengths supplied by the LEDs relative to the HPS lamps. Previous research has shown that increasing the percentage of blue wavelengths included in a radiation spectrum will inhibit stem extension and leaf expansion of bedding plant plugs (Randall and Lopez, 2014; Wollaeger and Runkle, 2015). For example, Randall and Lopez (2015) found that LA was reduced for petunia 'Dreams Midnight', impatiens 'Super Elfin XP Blue Pearl', and vinca 'Titan Dark Red' seedlings grown under sole-source LEDs with an increased percentage of blue radiation. Similarly, Wollaeger and Runkle (2015) found that $10 \mu \mathrm{mol} \cdot \mathrm{m}^{-2} \cdot \mathrm{s}^{-1}$ of blue radiation appeared to be sufficient for the stimulation of reduced stem length and LA for impatiens 'SuperElfin XP Red', salvia 'Vista Red', and petunia 'Wave Pink' seedlings grown under sole-source LEDs. 
Table 2. Macronutrient concentration [percent dry mass (DM)] of New Guinea impatiens, pepper, petunia, and zinnia seedlings, collected 21-28 d after germination, grown under supplemental lighting provided by light-emitting diode (LED) fixtures, high-pressure sodium (HPS) lamps, or no supplemental lighting (ambient).

\begin{tabular}{|c|c|c|c|c|c|c|}
\hline & \multicolumn{6}{|c|}{ Macronutrients (percent DM) } \\
\hline & Nitrogen & Phosphorus & Potassium & Sulfur & Calcium & Magnesium \\
\hline & \multicolumn{6}{|c|}{ New Guinea Impatiens } \\
\hline LED & $4.58^{\mathrm{z}} \mathrm{b}^{\mathrm{y}}$ & $0.40 \mathrm{~b}$ & $3.60 \mathrm{c}$ & $0.54 \mathrm{~b}$ & 1.65 & 0.83 \\
\hline HPS & $4.76 \mathrm{~b}$ & $0.39 \mathrm{~b}$ & $3.94 \mathrm{~b}$ & $0.57 \mathrm{ab}$ & 1.76 & 0.93 \\
\hline Ambient & $5.43 \mathrm{a}$ & $0.46 \mathrm{a}$ & $4.31 \mathrm{a}$ & $0.59 \mathrm{a}$ & 1.88 & 0.93 \\
\hline & \multicolumn{6}{|c|}{ Pepper } \\
\hline LED & $4.62 \mathrm{~b}$ & $0.35 \mathrm{~b}$ & $5.65 \mathrm{~b}$ & $0.42 \mathrm{~b}$ & 0.87 & $0.71 \mathrm{~b}$ \\
\hline HPS & $4.63 \mathrm{~b}$ & $0.34 \mathrm{~b}$ & $5.61 \mathrm{~b}$ & $0.45 \mathrm{~b}$ & 0.86 & $0.71 \mathrm{~b}$ \\
\hline Ambient & $5.51 \mathrm{a}$ & $0.44 \mathrm{a}$ & $7.46 \mathrm{a}$ & $0.58 \mathrm{a}$ & 0.92 & $0.87 \mathrm{a}$ \\
\hline & \multicolumn{6}{|c|}{ Petunia } \\
\hline LED & $4.17 \mathrm{c}$ & $0.33 \mathrm{~b}$ & $5.21 \mathrm{c}$ & $0.54 \mathrm{~b}$ & $0.86 \mathrm{c}$ & $0.51 \mathrm{c}$ \\
\hline HPS & $5.00 \mathrm{~b}$ & $0.33 \mathrm{~b}$ & $5.76 \mathrm{~b}$ & $0.54 \mathrm{~b}$ & $0.96 \mathrm{~b}$ & $0.58 \mathrm{~b}$ \\
\hline Ambient & $7.03 \mathrm{a}$ & $0.54 \mathrm{a}$ & $7.60 \mathrm{a}$ & $0.59 \mathrm{a}$ & $1.05 \mathrm{a}$ & $0.68 \mathrm{a}$ \\
\hline & \multicolumn{6}{|c|}{ Zinnia } \\
\hline LED & $4.52 \mathrm{c}$ & $0.33 \mathrm{~b}$ & $4.69 \mathrm{c}$ & 0.41 & $0.96 \mathrm{~b}$ & $0.81 \mathrm{c}$ \\
\hline HPS & $5.09 \mathrm{~b}$ & $0.34 \mathrm{~b}$ & $5.41 \mathrm{~b}$ & 0.41 & $1.10 \mathrm{a}$ & $0.90 \mathrm{~b}$ \\
\hline Ambient & $6.18 \mathrm{a}$ & $0.53 \mathrm{a}$ & $6.58 \mathrm{a}$ & 0.41 & $1.05 \mathrm{a}$ & $0.96 \mathrm{a}$ \\
\hline
\end{tabular}

${ }^{\mathrm{z}}$ Mean values are based on a representative sample from each treatment across two experimental replications.

${ }^{\mathrm{y}}$ Means sharing a letter are not statistically different by Tukey's honestly significant difference test at $P \leq 0.05$.

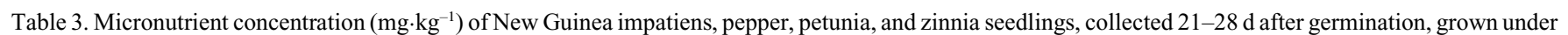
supplemental lighting provided by light-emitting diode (LED) fixtures, high-pressure sodium (HPS) lamps, or no supplemental lighting (ambient).

\begin{tabular}{|c|c|c|c|c|c|c|}
\hline & \multicolumn{6}{|c|}{ Micronutrients $\left(\mathrm{mg} \cdot \mathrm{kg}^{-1}\right)$} \\
\hline & Boron & Copper & Iron & Manganese & Molybdenum & Zinc \\
\hline & \multicolumn{6}{|c|}{ New Guinea Impatiens } \\
\hline LED & $22.48^{\mathrm{z}} \mathrm{b}^{\mathrm{y}}$ & $8.18 \mathrm{~b}$ & $231.6 \mathrm{~b}$ & $97.0 \mathrm{~b}$ & $1.10 \mathrm{~b}$ & $57.29 \mathrm{~b}$ \\
\hline HPS & $25.81 \mathrm{a}$ & $10.51 \mathrm{a}$ & $522.3 \mathrm{a}$ & $202.0 \mathrm{a}$ & $1.33 \mathrm{a}$ & $60.56 \mathrm{~b}$ \\
\hline \multirow[t]{2}{*}{ Ambient } & $24.13 \mathrm{ab}$ & $11.45 \mathrm{a}$ & $391.4 \mathrm{a}$ & $128.8 \mathrm{~b}$ & $1.30 \mathrm{a}$ & $73.64 \mathrm{a}$ \\
\hline & \multicolumn{6}{|c|}{ Pepper } \\
\hline LED & $30.53 \mathrm{~b}$ & 9.89 & 175.6 & 58.0 & $1.01 \mathrm{~b}$ & $54.90 \mathrm{~b}$ \\
\hline HPS & $32.61 \mathrm{~b}$ & 9.50 & 174.3 & 61.4 & $1.18 \mathrm{ab}$ & $60.23 \mathrm{ab}$ \\
\hline \multirow[t]{2}{*}{ Ambient } & $39.89 \mathrm{a}$ & 11.29 & 204.2 & 65.5 & $1.27 \mathrm{a}$ & $65.84 \mathrm{a}$ \\
\hline & \multicolumn{6}{|c|}{ Petunia } \\
\hline LED & $29.49 \mathrm{a}$ & $10.66 \mathrm{~b}$ & $123.3 \mathrm{~b}$ & $44.1 \mathrm{~b}$ & $2.55 \mathrm{~b}$ & $49.28 \mathrm{~b}$ \\
\hline HPS & $29.08 \mathrm{a}$ & $10.99 \mathrm{~b}$ & $266.1 \mathrm{a}$ & $73.2 \mathrm{a}$ & $2.33 \mathrm{~b}$ & $50.82 \mathrm{~b}$ \\
\hline Ambient & $23.63 \mathrm{~b}$ & $15.70 \mathrm{a}$ & $230.6 \mathrm{a}$ & $58.2 \mathrm{ab}$ & $3.38 \mathrm{a}$ & $76.57 \mathrm{a}$ \\
\hline & \multicolumn{6}{|c|}{ Zinnia } \\
\hline LED & $76.94 \mathrm{c}$ & $12.53 \mathrm{~b}$ & $269.1 \mathrm{~b}$ & $107.4 \mathrm{~b}$ & $1.58 \mathrm{a}$ & $31.14 \mathrm{c}$ \\
\hline HPS & $87.21 \mathrm{~b}$ & $12.91 \mathrm{~b}$ & $762.4 \mathrm{a}$ & $237.8 \mathrm{a}$ & $1.43 \mathrm{ab}$ & $38.37 \mathrm{~b}$ \\
\hline Ambient & $98.48 \mathrm{a}$ & $14.73 \mathrm{a}$ & $541.4 \mathrm{a}$ & $208.6 \mathrm{a}$ & $1.38 \mathrm{~b}$ & $63.74 \mathrm{a}$ \\
\hline
\end{tabular}

${ }^{\mathrm{z}}$ Mean values are based on a representative sample from each treatment across two experimental replications.

${ }^{\mathrm{y}}$ Means sharing a letter are not statistically different by Tukey's honestly significant difference test at $P \leq 0.05$.

Although the effect of blue radiation on plant morphology is evident in sole-source lighting applications, these responses often are inconsistent with those observed under greenhouse SL. In a greenhouse environment, the impact from the inclusion of blue radiation through SL is likely diminished due to ample blue wavelengths provided by solar radiation to saturate plant morphological responses (Poel and Runkle, 2017a). Therefore, under a high ambient DLI, the provision of blue radiation through SL often results in minimal plant responses. For example, Hernández and Kubota (2012) found that an ambient solar DLI of $8.9 \mathrm{~mol} \cdot \mathrm{m}^{-2} \cdot \mathrm{d}^{-1}$ provided sufficient blue radiation for the greenhouse production of tomato (Solanum lycopersicum 'Komeett') seedlings. Likewise, Poel and Runkle (2017a) evaluated HPS lamps and multiple LED fixtures, with radiation ratios providing $10 \%$ to $20 \%$ blue radiation, as sources of SL for the production of geranium 'Pinto Premium Salmon' and 'Ringo 200 Deep Scarlet', pepper 'Long Red Slim Cayenne', petunia 'Single Dreams
White' and 'Wave Misty Lilac', snapdragon 'Montego Yellow', and tomato 'Supersweet' seedlings with a target SL PPFD of 90 $\mu \mathrm{mol} \cdot \mathrm{m}^{-2} \cdot \mathrm{s}^{-1}$. With SL providing $20 \%$ to $40 \%$ of the total DLI in their study, they found very little difference in seedling dry matter accumulation or morphology regardless of the SL source or percentage of blue radiation. However, under a low ambient greenhouse DLI, impacts from the inclusion of blue radiation on plant morphology become more prevalent. For example, Randall and Lopez (2014) found that the height of multiple bedding plant species was reduced when seedlings were grown under LED SL providing $15 \%$ to $30 \%$ blue radiation with a target PPFD of $100 \mu \mathrm{mol} \cdot \mathrm{m}^{-2} \cdot \mathrm{s}^{-1}$ and a low ambient DLI of $<7 \mathrm{~mol} \cdot \mathrm{m}^{-2} \cdot \mathrm{d}^{-1}$. In addition, Hernández and Kubota (2014) found that under low-radiation conditions, with a DLI of $\approx 5.2 \mathrm{~mol} \cdot \mathrm{m}^{-2} \cdot \mathrm{d}^{-1}$, cucumber seedlings grown under LED SL with a greater percentage of blue radiation displayed decreased dry mass, leaf number, and LA. In the present study, SL provided $<33 \%$ of the average DLI for both the LED (10\% blue) and HPS ( $\approx 2 \%$ blue) SL treatments. Thus, minimal responses to additional blue radiation from LED SL were likely observed due to contributions from solar radiation.

Differences in LA and LAR for pepper and petunia between LED and HPS SL also may have been due to differences in leaf temperature between the two treatments. The emission of radiant heat is commonly associated with the use of HPS lamps and has been found to increase canopy temperature (Faust and Heins, 1997). Poel and Runkle (2017a) reported that leaf temperature relative to air temperature was 1 to $2{ }^{\circ} \mathrm{C}$ greater under HPS compared with LED SL. Although air temperature near the canopy was similar between SL treatments in the present study, leaf temperature was not measured. Thus, greater leaf temperatures under HPS SL may have been present and contributed to differences in LA and LAR observed for pepper and petunia compared with LED SL. However, for most species in the present study, no 
differences in LA or LAR were observed between SL sources.

A higher stem caliper, RDM, and SDM were observed under HPS and LED SL compared with seedlings grown under ambient radiation, although differences between the SL sources were not observed. Generally, an increased DLI results in increased dry mass per unit of fresh weight, which ultimately leads to thicker tissues (Faust et al., 2005). Multiple studies have shown that increased DLI leads to increases in the accumulation of RDM and SDM of young plants (Hernández and Kubota, 2014; Lopez and Runkle, 2008; Oh et al., 2010; Poel and Runkle, 2017b). For example, Lopez and Runkle (2008) observed that RDM and SDM of petunia 'Tiny Tunia Violet Ice', 'Double Wave Spreading Rose', and 'Supertunia Mini Purple' cuttings increased by $680 \%$ and $506 \%, 2395 \%$ and $106 \%$, and $108 \%$ and $147 \%$, respectively, as the propagation DLI increased from 1.2 to $8.4 \mathrm{~mol} \cdot \mathrm{m}^{-2} \cdot \mathrm{d}^{-1}$.

The QI assesses young plant quality by integrating morphological parameters linked to the perception of a high-quality seedling, with increased values generally indicating greater quality (Currey et al., 2013; Randall and Lopez, 2014). Sturdiness quotient and QI values were generally greater under both LED and HPS SL compared with ambient radiation, which can be attributed to the increased stem caliper, RDM, and SDM. In addition, greater SQ values were observed under LED compared with HPS SL for French marigold, pepper, and zinnia. Although differences were not always significant, seedlings grown under LED SL for these three species displayed shorter stem lengths compared with those produced under HPS SL, ultimately resulting in increased SQ values.

The greatest concentrations for both macro- and micronutrients were observed for seedlings grown under ambient radiation. This response is likely due to a dilution of the nutrient concentration due to the greater SDM observed under both LED and HPS SL. This dilution effect was suggested by Kuehny et al. (1991) after observing decreased foliar concentrations of nutrients under increased irradiance. These authors were able to remedy this effect through the expression of nutrient concentration on a starch-free dry weight basis (Kuehny et al., 1991). Thus, the greater nutrient concentrations observed under ambient radiation in the present study were likely due to the concurrent lower SDM observed.

Increased percentages of blue radiation have been linked to an increase in the concentration of many essential elements (Kopsell et al., 2014; Kopsell and Sams, 2013). However, select macro- and micronutrient concentrations were greater under HPS compared with LED SL for New Guinea impatiens, petunia, and zinnia in the present study. Thus, the increased blue radiation administered under LED SL did not have a positive effect on nutrient concentration. One possibility for the increased nutrient concentrations under HPS SL, compared with LED SL, is elevated leaf temperature. As discussed previously, the emission of radiant heat from HPS lamps has been associated with elevated leaf temperatures (Poel and Runkle, 2017a). Increased leaf temperature can increase stomatal opening (Urban et al., 2017), which may lead to greater nutrient concentrations via increased mass flow. However, future research is required to confirm this hypothesis.

Generally, SL source during propagation or finishing had little effect on TTF or finished plant quality. However, during finishing, greater height and SDM for ornamental millet, greater stem elongation for petunia, and a slight decrease in TTF for zinnia were observed when plants were grown under HPS SL compared with LED SL. Increased leaf temperatures due to the emission of radiant heat may have resulted in the increased growth and accelerated flowering for some species finished under HPS lamps. As mentioned previously, whereas canopy air temperatures between the two treatments were similar, it is possible that leaf temperature was greater under HPS SL. In addition, SL source during propagation had a limited effect on SDM at flowering, with increased values for gerbera and New Guinea impatiens when seedlings were grown under LED SL. Although differences were not significant, both gerbera and New Guinea impatiens seedlings produced greater RDM and SDM under LED compared with HPS SL during propagation. This increased dry matter accumulation may have led to accelerated establishment of transplants in the finishing environment, ultimately leading to increased SDM values at flowering.

The results from this study provide a practical comparison of LED and HPS SL for the production of bedding plant plugs and finished plant material in a commercial greenhouse. On the basis of these findings, we believe that LEDs may be used as an equivalent SL source to HPS lamps during both propagation and finish production. When the relative contribution of SL to DLI is low, spectral manipulation from LEDs for desired growth responses appears to be limited. Therefore, growers interested in SL installations can shift their primary focus from differences in plant quality and growth based on SL source to additional factors such as energy savings, price of the fixtures, and fixture lifespan.

\section{Literature Cited}

Albright, L.D., A.J. Both, and A.J. Chiu. 2000. Controlling greenhouse light to a consistent daily integral. Amer. Soc. Agr. Eng. 43:421431.

Cosgrove, D.J. 1981. Rapid suppression of growth by blue light. Plant Physiol. 67:584-590.

Currey, C.J. and R.G. Lopez. 2013. Cuttings of Impatiens, Pelargonium, and Petunia propagated under light-emitting diodes and highpressure sodium lamps have comparable growth, morphology, gas exchange, and post-transplant performance. HortScience 48:428-434.
Currey, C.J., A.P. Torres, R.G. Lopez, and D.F Jacobs. 2013. The quality index - a new tool for integrating quantitative measurements to assess quality of young floriculture plants. Acta Hort. 1000:385-391.

Fausey, B.A., R.D. Heins, and A.C. Cameron. 2005. Daily light integral affects flowering and quality of greenhouse-grown Achillea, Gaura, and Lavandula. HortScience 40:114118.

Faust, J.E. and R.D. Heins. 1997. Quantifying the influence of high-pressure sodium lighting on shoot-tip temperature. Acta Hort. 418:85-91.

Faust, J.E., V. Holcombe, N.C. Rajapakse, and D.R. Layne. 2005. The effect of daily light integral on bedding plant growth and flowering. HortScience 40:645-649.

Franklin, K.A. 2008. Shade avoidance. New Phytol. 179:930-944.

Frantz, J.M. 2013. Uptake efficiency of phosphorus in different light environments by zinnia (Zinnia elegans) and vinca (Catharanthus roseus). HortScience 48:594-600.

Graper, D.F. and W. Healy. 1992. Modification of petunia seedling carbohydrate partitioning by irradiance. J. Amer. Soc. Hort. Sci. 117:477480.

Hernández, R. and C. Kubota. 2012. Tomato seedling growth and morphology responses to supplemental LED lighting red:blue ratios under varied daily solar light integrals. Acta Hort. 956:187-194.

Hernández, R. and C. Kubota. 2014. Growth and morphological response of cucumber seedlings to supplemental red and blue photon flux ratios under varied solar daily light integrals. Scientia Hort. 173:92-99.

Hunt, R. and J.H.C. Cornelissen. 1997. Components of relative growth rate and interrelations in 59 temperate plant species. New Phytol. 135:395-417.

Hutchinson, V.A., C.J. Currey, and R.G. Lopez. 2012. Photosynthetic daily light integral during root development influences subsequent growth and development of several herbaceous annual bedding plants. HortScience 47:856860 .

Kigel, J. and D.J. Cosgrove. 1991. Photoinhibition of stem elongation by blue and red light. Plant Physiol. 95:1049-1056.

Kopsell, D.A. and C.E. Sams. 2013. Increase in shoot tissue pigments, glucosinolates, and mineral elements in sprouting broccoli after exposure to short-duration blue light from lightemitting diodes. J. Amer. Soc. Hort. Sci. 138: 31-37.

Kopsell, D.A., C.E. Sams, T.C. Barickman, and R.C. Morrow. 2014. Sprouting broccoli accumulate higher concentrations of nutritionally important metabolites under narrow-band light-emitting diode lighting. J. Amer. Soc. Hort. Sci. 139:469-477.

Kuehny, J.S., M.M. Peet, P.V. Nelson, and D.H. Willits. 1991. Nutrient dilution by starch in $\mathrm{CO}_{2}$-enriched chrysanthemum. J. Expt. Bot. 42:711-716

Lopez, R., C. Currey, and E. Runkle. 2017. Light and young plants, p. 109-118. In: R. Lopez and E. Runkle (eds.). Light management in controlled environments. Meister Media Worldwide, Willoughby, $\mathrm{OH}$.

Lopez, R.G. and E.S. Runkle. 2008. Photosynthetic daily light integral during propagation influences rooting and growth of cuttings and subsequent development of New Guinea impatiens and petunia. HortScience 43:2052-2059.

Mitchell, C.A., A. Both, C.M. Bourget, J.F. Burr, C. Kubota, R.G. Lopez, R.C. Morrow, and E.S. 
Runkle. 2012. LEDs: The future of greenhouse lighting! Chronica Hort. 52:6-12.

Morrow, R.C. 2008. LED lighting in horticulture. HortScience 43:1947-1950.

Nelson, J.A. and B. Bugbee. 2014. Economic analysis of greenhouse lighting: Light emitting diodes vs. high intensity discharge fixtures. PLoS One 9:e99010, doi: 10.1371/journal. pone.0099010.

Oh, W., E.S. Runkle, and R.M. Warner. 2010 Timing and duration of supplemental lighting during the seedling stage influence quality and flowering in petunia and pansy. HortScience 45:1332-1337.

Poel, B.R. and E.S. Runkle. 2017a. Seedling growth is similar under supplemental greenhouse lighting from high-pressure sodium lamps or lightemitting diodes. HortScience 52:388-394.

Poel, B.R. and E.S. Runkle. 2017b. Spectral effects of supplemental greenhouse radiation on growth and flowering of annual bedding plants and vegetable transplants. HortScience 52:12211228.

Pramuk, L.A. and E.S. Runkle. 2005. Photosynthetic daily light integral during the seedling stage influences subsequent growth and flowering of Celosia, Impatiens, Salvia, Tagetes, and Viola. HortScience 40:1336-1339.

Randall, W.C. and R.G. Lopez. 2014. Comparison of supplemental lighting from high-pressure sodium lamps and light-emitting diodes during bedding plant seedling production. HortScience 49:589-595.

Randall, W.C. and R.G. Lopez. 2015. Comparison of bedding plant seedlings grown under sole-source light-emitting diodes (LEDs) and greenhouse supplemental lighting from LEDs and highpressure sodium lamps. HortScience 50:705-713.

Runkle, E.S. and R.D. Heins. 2001. Specific functions of red, far red, and blue light in flowering and stem extension of long-day plants. J. Amer. Soc. Hort. Sci. 126:275-282.
Stutte, G.W. 2009. Light-emitting diodes for manipulating the phytochrome apparatus. HortScience 44:231-234.

Styer, R.C. 2003. Propagating seed crops, p. 151163. In: D. Hamrick (ed.). Ball redbook crop production. Vol. 2. 17th ed. Ball Publishing, Batavia, IL.

Urban, J., M.W. Ingwers, M.A. McGuire, and R.O. Teskey. 2017. Increase in leaf temperature opens stomata and decouples net photosynthesis from stomatal conductance in Pinus taeda and Populus deltoides $\times$ nigra. J. Expt. Bot. 68:1757-1767.

Wallace, C. and A.J. Both. 2016. Evaluating operating characteristics of light sources for horticultural applications. Acta Hort. 1134: 435-444.

Wollaeger, H.M. and E.S. Runkle. 2015. Growth and acclimation of impatiens, salvia, petunia, and tomato seedlings to blue and red light. HortScience 50:522-529. 